\title{
The Knowledge-Base of Pre-Service and in-Service Iranian EFL Teachers in Teacher Education Programs
}

\author{
Rahman Sahragard \\ Prof., Shiraz University, Iran, rahman.sahragard@gmail.com
}

\section{Leila Saberi}

Department of English, Marvdasht Branch, Islamic Azad University, Marvdasht, Iran, saberi500@yahoo.com

\begin{abstract}
This study investigated the knowledge base of pre-service and in-service teacher education in Iran. In so doing, a teacher education knowledge base, and a knowledge base effectiveness questionnaire, developed by Jadidi and Bagheri (2014) were used. The participants selected through convenient sampling were 140 student teachers, the pre-service group, and 160 practicing teachers, the in-service group. The respondents were asked to indicate the extent to which the topics are included in pre and in-service programs as well as the extent to which such areas are effective for teaching. The findings showed that among the seven components extracted from the questionnaires, knowledge areas like material development, post-method indicators and research methods are not adequately covered in preservice programs with their means $1.46,1.54$, and 1.62 respectively. Similarly, for the in-service teachers, issues like, teacher awareness, post-method and research methods had the lowest means, as $1.64,1.66$, and 1.71 respectively. Instead, language concepts and theoretical principles are covered the most. The results also indicated that from the perspective of pre-service teachers, learners' individual characteristics, language acquisition, and research methods are the most effective areas for teaching with their means $2.82,2.71$, and 2.45 respectively while material development, post-method indicators, and teacher awareness are the least useful areas with their means $1.65,1.73$, and 2.35 respectively.
\end{abstract}

Keywords: knowledge-base, pre-service program, in-service program, teacher education, teaching

\section{INTRODUCTION}

One of the goals of language teaching is to advance students' learning. To improve classroom teaching in a firm and convincing way, the teaching profession requires a knowledge base that brings about change in teachers' performance. In fact, teachers need to be equipped with different kinds of knowledge and skills to establish and

Citation: Sahragard, R., \& Saberi, L. (2018). The Knowledge-Base of Pre-Service and in-Service Iranian EFL Teachers in Teacher Education Programs. International Journal of Instruction, 11(4), 445-466. https://doi.org/10.12973/iji.2018.11428a 
maintain helpful teaching environments that pave the ground to reach pre-determined goals. Elbaz (1983, p.11) claimed that "the single factor, which seems to have the greatest power to carry forward our understanding of the teachers' role is the phenomenon of teachers' knowledge". Conceptualizing teacher knowledge is a complex issue that needs understanding some underlying phenomena including the process of teaching and learning, the concept of knowledge, as well as the way teachers' knowledge is put into action in the classroom (Guerriero, 2014).

The topic of teacher knowledge and the essence of the knowledge base have been recognized as the leading concerns of research in language teacher education over the last few years; that is why an increasing interest can be noticed in evaluating the effectiveness of teacher education processes and how teachers and students interpreted the teacher education programs they experienced (Zeichner, 1999). This was, in fact, an incentive to the emergence of a number of theoretical models on teachers' knowledge' base. Fandino (2013) presented an overview of these models for L2 teachers by referring to Shulman's (1987) pedagogical reasoning and action model, Calderhead's (1988) teachers' professional learning model, Wallace's (1991) craft model, the applied science model and the reflective model, Freeman's (1991) interteaching model, Day's (1993) apprentice-expert model, Manouchehri's (2002) cultural model and Ohata's (2007) self-awareness and reflection model. Investigating all the above mentioned models, Schulman's (1987) model of the knowledge base of teaching can be called as the most persuasive of all and it is made up of a set of various categories of knowledge; 1. Content knowledge; 2. General pedagogical knowledge (pedagogical issues that transcend subject matter); 3. Curriculum knowledge; 4. Pedagogical content knowledge (the amalgam of content and pedagogy that is uniquely the province of the teacher); 5 . Knowledge of learners and their characteristics; 6 . Knowledge of educational context (at both micro- and macro-levels); 7. Knowledge of educational ends, purposes, and values (p.97).

In a globalized world where the English language is used as an international instrument, teaching English has become a field which is worthwhile investigating within the general educational system. Thus, it is vital for teacher educators and policy -makers to adopt the most appropriate teacher education model which can in turn help teachers to be equipped with an effective knowledge base. Moon, et al. (2005) believed that most teacher education falls into one of the three categories: (1) pre-service education and training (2) in-service qualification and upgrading, and (3) continuing professional development. According to Richards and Schmidt (1985), pre-service training is a course program of study which student teachers undertake before they practice teaching. It often provides future teachers with basic teaching techniques and gives them a general background in teaching and their subject matter. As Lucas, et al. (2008) explained, today's teachers need a broad range of knowledge and skills, including deep content knowledge, pedagogical content knowledge, knowledge of how children learn in a variety of settings, skills for creating classroom community that is supportive of learning, knowledge about multiple forms of assessment, and the ability to reflect on practice. They explained that pre-service teacher education programs can involve prospective teachers in different types of activities which can prepare them to learn 
about English language learners in their future class. In- service teacher education, on the other hand, as described by Nelson (2007) refers to workshops and lectures designed to keep practicing teachers informed about current practices in their field. Richards and Schmidt (1985) asserted that in-service education concerns the experiences provided for teachers who are already teachers and forms part of their continued professional development. Richards and Rogers (1985) maintained that in-service training is held for a specific purpose and involves a number of activities such as "assessing participants needs, determining objectives for in-service programs, planning content, choosing methods of presentations and learning experiences, implementing, evaluating effectiveness and providing follow-up assistance" (p.416). However, Casey and McWilliam (2008) claimed that providing in-service teachers with workshops consisting of lectures, discussions and simulations has been associated with weak and inconsistent changes in teacher behaviour. In other words, they argued that such programs have little or nothing to do with teachers' practical teaching. This can imply that there is a need for a change in the current in-service programs so that they can fulfil the intended goals. This way, teachers can benefit from the programs and apply the presented issues in their own classrooms.

Due to the importance of teacher education programs, it is necessary to have an organized evaluation system for both pre-service and in-service teacher training programs. Peacock (2009) believed that this evaluation is necessary for the professionalization of the field of English language teaching (ELT), which can actually lead to program development as well. In fact, it is important to show the aspects of the programs that require improvement from teachers' points of view. There are a number of researchers who made recommendations regarding the content and procedures of ELT programs. Wedell (1992) suggested that these programs should balance the essential components of ELT training _linguistic, pedagogic and managerial competence. Kumaravadivelu (2012) believed that these models often limit the role of teacher educators to conductors, comprise a master-pupil relationship, and rarely encourage student teachers to construct their own teaching visions, mainly have the topdown approach, and create a diminishing dichotomy between the expert and the teacher.

Pre-service training programs should provide evidence that they are preparing teacher trainees for their teaching career. Therefore, it is vital for teacher educators to evaluate such programs. However, literature contains few reports on the evaluation of pre-service teacher education programs in Iran as an EFL context to see what knowledge base areas are covered and how effective they are for practical teaching. Khanjani, et al. (2016) reported that such programs had not been adequately laid-out and some changes were needed to improve them. Razi and Kargar (2014) argued that a program cannot be improved without evaluation, which is emphasizing its strengths and eliminating the weak points. The findings of their study showed that in-service programs in Iran suffered from a number of shortcomings, including the poor administration of the courses. In-service teacher training programs are also intended to address the issues that practicing teachers may encounter while practical teaching and equip them with the necessary knowledge. Considering the time and budget put into such programs, it is important to analyse them carefully to find out whether they satisfy the assumed 
objectives. Kazemi and Ashrafi (2014) asserted that in-service programs were not academically adequate and they were useless. They added that these programs could not convey any new knowledge to teachers. In other words, the knowledge areas covered in such programs were not considered effective for practical teaching.

Concerning the importance of teachers' knowledge base provided in both pre-service and in-service teacher education programs, it seems vital to investigate these programs to find out how effective they are and check whether they help prospective and practicing teachers with their professional development. In so doing, this study is mainly researching teacher education knowledge base in Iran as an EFL context based on Kumaravadivelu's modular model of teacher education (2012). This model has five modules- knowing, analysing, recognizing, doing, and seeing. The knowing module is related to the knowledge base teachers need and introduces three types of knowledge (a) professional knowledge; (b) procedural knowledge; and (c) personal knowledge. Preservice and in-service teaching training programs, books, journals, conferences, etc. are sources of professional knowledge for teachers. This knowledge entails the fundamental concepts of language, language learning, and language teaching. Procedural knowledge is related to knowing how to manage classroom learning and teaching and creating a classroom environment in which effective learning outcomes are attained. Both of these two mentioned types of knowledge represent collective wisdom of the expert, while personal knowledge reflects the individual effort of the teacher. It shows teachers' reflection and reaction. The assumption in the analysing module is that $\mathrm{L} 2$ teachers must develop the knowledge and skills necessary to analyse learner needs, learner motivation, and learner autonomy if they want to carry out their responsibility successfully. The recognizing module is based on the assumption that teachers must recognize Self that is their identity, beliefs, and values which can actually play a crucial role in determining their teaching behaviour and shaping learning outcomes. As Kumaravadivelu (2012) stated, the three modules, knowing, analysing, and recognizing will be useless if the doer is not doing. The doing module of teacher education consists of three parts: teaching that advances desired learning outcomes, theorizing that requires a personal theory of practice and dialogizing that involves critical conversations with informed interlocutors. The last module, seeing, emphasizes critical classroom observation and the need for teacher, learner, and observer perspectives through self as well as peer observation. Each of the five modules is seen as independent as well as interdependent. It is independent in the sense that each can stand on its own in terms of specific goal and expected outcomes. It is interdependent in the sense that each one can shape and is shaped by the other. Therefore, this model incorporates a network of mutually reinforcing as well as retaining sub-systems (Kumaravadivelu, 2012).

\section{LITERATURE REVIEW}

\section{What is Considered as Teachers' Knowledge-Base?}

As Pineda (2002) asserted, for decades, the conceptualization of teachers' knowledge was limited to attaining the basic skills for teaching, having the teacher educators competent in their subject matter area, and using pedagogical strategies. According to 
Fandino (2013), other critical issues in teaching including the classroom context, the physical and psychological characteristics of the learners, the personal and practical experiences of teachers, and reflective practices and research skills must be considered. During the last few decades, a variety of proposals have been generated. Kaur, et al. (2011) believed that an effective teacher needs to master at least two types of basic knowledge: content knowledge and pedagogical knowledge. While the former refers to teachers' knowledge of subject matter, the latter is related to the teaching and learning of subjects and their curricula. Shulman (1987) proposed a framework that includes content, pedagogy, curriculum, and context. In this framework, three types of content knowledge exist (a) subject matter knowledge, (b) pedagogical content knowledge and (c) curricular knowledge. There are also other categories such as knowledge of learners, knowledge of pedagogy, knowledge of educational context, and knowledge of educational ends. Fenstermacher (1994) distinguished formal knowledge from practical knowledge, where the first one is based on literature derived from research on effective teaching and the second one resulting from teachers' experiences and reflection within the classroom context, is generated by teachers.

In the field of second language teaching, a number of proposals about what constitutes knowledge base have emerged. Lafayette (1993) argued that, there are three domains of L2 teachers' knowledge: language proficiency, civilization and culture, and language analysis. As he stated, if teachers want to be effective users and models, they should have an advanced command of the language. Related to civilization and culture, L2 teachers should be aware of issues like literature and customs in order to help their students develop cultural awareness towards unfamiliar people and things. Regarding language analysis, Lafayette mentioned that L2 teachers should not only know about language structures, but also be informed about applied linguistics and language acquisition.

Day's (1993) framework included four domains of knowledge: content knowledge, pedagogical knowledge, pedagogic content knowledge, and support knowledge. Content knowledge refers to the knowledge of subject matter with issues like phonology, pragmatics, syntax, etc. Pedagogic knowledge is related to the knowledge of teaching practices such as classroom management. While pedagogic content knowledge concerns the specialized knowledge of L2 teaching (grammar, speaking, etc.), support knowledge deals with the knowledge of different disciplines like sociolinguistics that can assist language teachers with their approaches to L2 teaching and learning. Following Shulman, Richards (1998) introduced six dimensions of knowledge base: theories of teaching, teaching skills, communication skills and language proficiency, subject matter knowledge, pedagogical reasoning and decision making, and contextual knowledge. Richards believed that if these dimensions are developed, L2 teachers can understand the realities of their classroom and advance their educational experiences which can finally cause reflection and change. Freeman and Johnson (1998) proposed a reconceptualization of teacher knowledge base in a sense that language teaching can be improved if it is systematically examined how language teachers come to know what they know and do what they do in their work. This implies that the socio-cultural context in which learning takes place must be taken into consideration which is actually a more 
highlighted focus on the activity of teaching, the teacher who does it, and the pedagogy by which it is done. They suggested three integrated dimensions (a) the teacher as a learner of language teaching, (b) schools and schooling as historical and socio-cultural contexts for teacher learning, and (c) the teachers' pedagogical thinking about teaching, the subject matter and its content and the language learning processes. These are all the factors which can ultimately help teachers understand and develop their knowledge base. In 2005, however, Tarone and Allwright argued that Freeman and Johnson's framework of teachers' knowledge base lacks a critical component: the second/foreign language learner, which is learners' clear understanding of who they are, why they learn, what they need to learn, and what motivates them.

As it can be noticed, each framework investigated teachers' knowledge base from a different perspective and as a result each had its own strengths and weaknesses. This can imply that teacher educators should design teacher education programs, both pre and inservice programs, in a way that the most effective knowledge areas for teaching are included.

\section{A Closer Look at Teacher Education in Iran}

There are three branches of English majors in Iran for which English language teachers are recruited, namely, literature, translation, and teaching. The available programs for these teachers are divided into two categories: general English courses and special major courses, where the first one aims to enhance general English proficiency and the second one is designed to increase students' knowledge of a specific major. In English education which is still in its pre-technology level in Iran, the teacher acts as the sender and the student is the receiver of the information. Safi (1992) stated that the early teachers in Iran were selected from studious students without receiving any education. In the 1940s, however, some developments in teacher education were observed and some authors such as Dehghan (1950) emphasized the education of qualified teachers. Following that, different training canters were established, but still, no teacher educating existed. In fact, while the teaching atmosphere was dominated by modernism ideas, no signs of postmodernism were noticed. Decisions were made by the educational system with a one-size-fits-all policy and a conservative centralized approach where no attention was paid to the individual differences among teachers, learners, and contexts. Noora (2008) noted that the nature of teaching in Iran is mainly teacher-centred where teachers have no opportunity to say about their own expectations of an effective teacher.

In Iran, teacher education programs have been successful in improving teachers' theoretical knowledge, in a sense that, they are informed about the theoretical underpinnings, language teaching history, and different methodologies and their principles. However, there is little or no opportunity for teachers to practice what they have read in books. That is why, when they enter the real world of teaching, a number of challenges arise. In addition, university teachers and teacher educators are considered as the only source of information which is provided through a process-product procedure. It is also worth mentioning that, since practical courses are scarcely provided in teacher education programs, teachers have little chance to practice the real atmosphere of the classroom. 


\section{Evaluating Teacher Education Programs in Iran}

As Shahmohammadi (2012) stated, there are a number of social or cultural problems that we face in Iran among which the improvement of the education system is the most serious one. This problem requires investigation in order to meet the needs of the young generation which can in turn lead to social progress. Teachers play a key role in social and cultural changes and as Lynch and Plunket (1973) emphasized, much of the vision, expertise, and cultural sensitivity to interpret and respond to pressure for change and start qualitative progress in education come from teachers. That is why the selection and preparation of teachers to produce the best of them are of crucial concerns.

Dr. Cooms (as stated in Shahmohammadi, 2012, p.128), drew our attention to the important role of teacher preparation and said, "Education system will not be modernized until the whole system of teacher-training is drastically intellectually richer and more challenging, and extend far beyond pre-service training into a system for continuous professional reward and career development for all teachers". Shahmohammadi (2012) argued that teacher education programs for the future should consider new teacher roles, apply technology to create new approaches to teaching and consider the needs of learners. Related to teacher preparation in Iran, she further added that a number of social problems are ignored such as the respect for the teaching profession, the needed services to the country and humanity, and attitudes about the ideals of democracy.

\section{Empirical Evaluation of Teacher Education Programs}

Mehrani and Mohammadi (2016) conducted a study that focused on a language teacher professional development initiated in 2013 at the request of the head of the university and took the form of a pre-service professional teacher education program. It aimed at investigating the effectiveness of pre-service language teacher education program at Farhangian University of Bojnourd. Results showed that teaching methodology courses are often overfilled with theoretical discussions, but prospective teachers demanded more practical courses and further opportunities to practice teaching in real classes. They expressed their concerns regarding the importance of oral communication skills and emphasized that English conversation courses must be considered more seriously. The findings also suggested that more collaborative activities are needed so that student teachers can share their experiences, reflect on their current abilities and get instructional feedback from each other as well as from their masters.

Mirhassani and Beh-Afarin (2004), in a survey-based study, evaluated the status of preservice EFL teacher training program in Iran. The results indicated that the participants were dissatisfied with the current situation of the program, there was a gap between desired and present situation; communicative approaches could be hardly incorporated into the program, and a majority of participants expressed a need for a revision in the program. In their study, Khanjani, et al. (2017) tried to evaluate pre-service teacher education program in Iran to find whether such programs can promote prospective teachers' knowledge base. For the majority of the participants, the main problems of the program were: (a) the structure and layout of the program were not appropriate; (b) 
there was a lack of systematic needs analysis; (c) most courses did not target the teacher trainees' requisite skills and knowledge; (d) the materials were outdated and did not help the prospective teachers to put the pedagogical content knowledge into practice; (e) the teaching activities were not adequate to give rise to the teacher trainees' professional knowledge; (f) there was a lack of qualified teacher educators; (g) they emphasized lecture-based methodology; ( $g$ ) they focused on theoretical aspects of teaching; (h) they used irrelevant coursed; (i) excessive use of L1, low general proficiency of teacher trainees, heterogeneity of the teacher trainees, their low motivation, and inadequacy of assessment procedures were also among the problems expressed.

Shahmohammadi (2012) attempted to gather information relevant to the status of preservice and in-service programs for teachers in Iran. She specifically tried to find out aims of in-service programs, their organization, nature of the curriculum, the methods of teaching, techniques of evaluation, the educational agencies involved in the program and its strengths and weaknesses. The results showed that there were specified and defined and defined objectives, the organization was satisfactory, teaching methods were lecture and conference, and the method of evaluation was written method. The researcher concluded, "It could be said that the Iranian system of teacher education and in-service teacher training prepares teachers well for work in schools" (p.134). Razi and Kargar (2014) conducted a study that aimed at evaluating the current in-service foreign language teacher education program in Iran to help improve it. The results revealed that the status of the current program is not satisfying with regard to improving English teachers' language proficiency level, teaching skills, management skills, and evaluation skills. It was also shown that the program suffered a relative inadequacy with regard to increasing teachers' motivation and the administration of the courses. The program was also found to have some merits like preparing teachers for using foreign language teaching materials, presenting certificates which have positive effects on teachers' evaluation and an opportunity for them to exchange their ideas with other colleagues.

\section{Purpose of the Study}

Considering the fact that English teacher education research has not yet been well developed in scope and design in Iran, and teacher training programs, both pre-service and in-service, suffer from a number of weaknesses, the researcher hopes to pave the ground for the stakeholders' more plenary understanding of the field. It, therefore, intended to investigate the knowledge base areas which are covered in both pre-service and in-service teacher education programs and their degree of effectiveness as perceived by prospective and practicing Iranian EFL teachers.

During the last few decades, a growing recognition has occurred relating to the attention paid by educators to the significant role of teachers in students' achievement. So, in English teaching profession, teachers need to expand their knowledge and improve their abilities. This would not happen unless teachers are equipped with effective knowledge base which is mainly provided through teacher education training programs. Indeed, there is no doubt that if these programs are effective, they will have positive impacts on students' learning outcomes. With this in mind, it is hoped that this study can make contributions to the field of EFL teaching and learning. It can help gain useful insights 
to the knowledge base areas covered during teacher education programs, to know whether they are helpful for effective teaching and learning and determine if they assist teachers with their teaching profession. The findings can be insightful for teachers and practitioners as well as researchers and teacher educators in EFL pedagogy. Universities and schools may enjoy the findings of the present study while planning different training programs and evaluating them. Hence, studies of this kind can pave the ground to investigate the effectiveness of English teachers' knowledge base in both pre-service and in-service teacher education programs in Iran and find their strengths and weaknesses based on prospective and practicing teachers' point of view.

\section{Research Questions}

R.Q.1. What types of knowledge are covered during pre-service and in-service teacher education programs in Iran, based on knowing, analysing, and recognizing parts of Kumaravadivelu's modular model (2012)?

R.Q.2. To what extent the knowledge areas covered during pre-service and in-service teacher education programs are found to be effective for practical teaching from the perspectives of Iranian EFL student teachers and practicing teachers?

\section{METHOD}

\section{Participants}

This study used convenient sampling through which 300 male and female student teachers and practicing teachers were asked to participate in the study. Out of 300 participants, 140 were pre-service student teachers from Farhangian University and 160 were practicing teachers form Farhangian University and other state universities with the experience of passing different in-service programs.

\section{Instrument}

In order to conduct this study, the researcher used two questionnaires, called teacher education knowledge base(TEKB) and knowledge base effectiveness(KBE), designed and developed by Jadidi and Bagheri (2014) (see Appendix A and B). To ensure the validity of the questionnaires, they used three sources of evidence, namely, content validity (as approved by expert group), reliability (.898 for TEKB, .957 for KBE) and construct validity (extracting the factors involved in the questionnaires). The literature on second or foreign language teacher education, teacher cognition, EFL professional development, Kumaravadivelu modular model (2014), and also interviews with some ELT teacher educators who had the experience of teaching courses at different teacher training programs, were all the contributing sources for designing these questionnaires.

\section{Procedure and Data Analysis}

In order to conduct the study, a small number of Iranian EFL teachers were selected based on their availability and willingness to take part in the study, as a sample for performing a focus group interview to see if any changes or revisions on the questionnaires were needed. The results indicated that all the necessary items were 
included and no changes were needed. Then, both questionnaires were distributed among 300 Iranian EFL student teachers and practicing teachers from different educational contexts such as Farhangian University, Azad University, and other state universities like Payam-e-Nour. They were either emailed or submitted by hand to the participants in both groups. Before administering the questionnaires, the respondents were provided with some explanations about the aim of the study in order to avoid possible ambiguities.

In order to analyse the questionnaires data, the Statistical Package for Social Sciences (SPSS) software version 21 was used. To find the attitudes of the teachers towards the knowledge base areas covered in both pre-service and in-service group, the quantitative data obtained from the TEKB Questionnaire were analyzed by descriptive statistics (means and standard deviations) as a way to find issues and concepts presented during teacher education training programs. Moreover, the quantitative data obtained from KBE Questionnaire were analyzed by descriptive statistics (means and standard deviations) to find the effectiveness of the knowledge base covered in both groups. To see the differences between the two groups of teachers in their attitudes towards the knowledge base areas covered in teacher education training programs and the effectiveness of such knowledge, the mean scores of the underlying components of the questionnaires were taken into consideration and were compared.

\section{FINDINGS}

In this part, the statistical results with respect to each research question, using tables, are provided.

R.Q.1. What types of knowledge are covered during pre-service and in-service teacher education programs in Iran, based on knowing, analysing, and recognizing parts of Kumaravadivelu's modular model (2012)?

In order to explore the knowledge base presented to teachers during their pre-service and in-service teacher education programs in Iran, the 45 item TEKB questionnaire was administered to 140 pre-service student teachers and 160 in-service practicing teachers. The Mean scores of the underlying components of the questionnaire were taken into consideration to determine the perceived coverage of knowledge base areas in such programs. The results are presented in Table1.

Table 1

The Knowledge Base of Pre-Service Teacher Education

\begin{tabular}{llllll}
\hline & $\mathrm{N}$ & Minimum & Maximum & Mean & Std. Deviation \\
\hline Materials development & 140 & 1.00 & 3.50 & 1.4607 & .32613 \\
\hline post method & 140 & 1.00 & 2.17 & 1.5417 & .33580 \\
\hline Research skills & 140 & 1.14 & 2.43 & 1.6520 & .46147 \\
\hline awareness & 140 & 1.40 & 2.40 & 1.7071 & .30479 \\
\hline Learner issues & 140 & 1.38 & 3.00 & 2.2348 & .46710 \\
\hline Language concepts & 140 & 1.50 & 3.75 & 2.5661 & .52510 \\
\hline Theoretical principals & 140 & 1.33 & 3.33 & 2.6310 & .65724 \\
\hline Valid N (listwise) & 140 & & & & \\
\hline
\end{tabular}


Table 1 indicates that language concepts and theoretical issues are rather noticeably more emphasized as they have respectively received the highest means (2.6310 and 2.5661). The perceived coverage of knowledge base areas related to research skills (1.6520), post method pedagogy (1.5417), and materials development (1.4607) is relatively low in pre-service teacher education in Iran. Learner issues is also perceived to be moderately addressed as the mean score is slightly less than the half of the possible maximum score (2.23 out of 5). From the perspective of pre-service teachers, therefore, issues and concepts related to material development, post method indicators and research methods in SLA are not sufficiently covered in pre- service teacher education in Iran and language concepts and theoretical principles are emphasized over other knowledge base areas in pre-service teacher education in Iran.

Table 2

The knowledge Base of In-Service Teacher Education

\begin{tabular}{llllll}
\hline & $\mathrm{N}$ & Minimum & Maximum & Mean & Std. Deviation \\
\hline Language concepts & 160 & 1.00 & 2.75 & 2.4631 & .33769 \\
\hline Learner issues & 160 & 1.00 & 2.67 & 2.3287 & .41763 \\
\hline Materials development & 160 & 1.00 & 2.75 & 1.3531 & .39948 \\
\hline Research skills & 160 & 1.00 & 3.29 & 1.7170 & .43214 \\
\hline post method & 160 & 1.00 & 6.75 & 1.6623 & .64643 \\
\hline Awareness & 160 & 1.00 & 3.40 & 1.6478 & .51679 \\
\hline Theoretical principles & 160 & 1.50 & 4.50 & 3.0333 & .62830 \\
\hline Valid N (listwise) & 160 & & & &
\end{tabular}

A similar phenomenon can be inferred for in-service teacher education in Iran based on the results presented in Table 2. In-service teachers also admitted that the content of teacher education in Iran is more allocated to theoretical concepts rather than contextsensitive issues (post-method, awareness and research skills). The highest and the lowest perceived coverage have been attributed to theoretical principles and materials development respectively.

Comparing Tables 1 and 2, it is noticed that both pre and in-service teachers hold the belief that traditional knowledge areas such as language concepts, theoretical principles and learner issues are more emphasized or covered in teacher education system prevalent in Iran either pre-service or in-service, rather than those that have attracted the scholars' and practitioners' attention during the last two decades such as teacher awareness, post-method indicators and research skills. Such findings highlight the necessity for a serious re-assessment and specification of the content of the teacher education programs. In order to decide on the significance of the differences in the views of pre and in-service teachers mentioned and elaborated above, Multivariate analysis of variance was embarked on. The results are presented in Table 3, Table 4, and Table 5.

Table 3

Between-Subjects Factors

\begin{tabular}{lllc}
\hline & \multicolumn{1}{c}{ Value Label } & $\mathrm{N}$ \\
\hline Gro & 1 & in-service & 160 \\
\cline { 2 - 4 } $\operatorname{up}$ & 2 & pre-service & 140 \\
\hline
\end{tabular}


Inspecting the Column which is entitled "Wilks' Lambda" in the group section of Table 4, one can notice that there is not any significant difference between pre-service and in-service teachers' attitudes towards the knowledge base areas that are commonly covered in teacher education programs in Iran. However, Tests of Between-Subjects Effects should also be inspected to check the significance of the differences among all dependent variables, the knowledge areas. Table 5 illustrates the respective results.

Table 4

Multivariate Tests ${ }^{\mathrm{a}}$

\begin{tabular}{lllllll}
\hline Source & Dependent Variable & $\begin{array}{l}\text { Type III Sum } \\
\text { of Squares }\end{array}$ & df & $\begin{array}{l}\text { Mean } \\
\text { Square }\end{array}$ & F & Sig. \\
\hline \multirow{5}{*}{ group } & Issues & .553 & 1 & .553 & 3.793 & .352 \\
\cline { 2 - 7 } & Theory & 11.870 & 1 & 11.870 & 28.685 & .030 \\
\cline { 2 - 7 } & Language & 44.579 & 1 & 44.579 & 273.763 & .441 \\
\cline { 2 - 7 } & Teacher awareness & 8.099 & 1 & 8.099 & 45.131 & .291 \\
\cline { 2 - 7 } & Research & 4.747 & 1 & 4.747 & 23.947 & .336 \\
\cline { 2 - 7 } & Post-method & 27.396 & 1 & 27.396 & 77.466 & .091 \\
\cline { 2 - 7 } & Materials & 5.971 & 5.971 & 44.621 & .450 \\
\hline
\end{tabular}

Table 5

Tests of Between-Subjects Effects

\begin{tabular}{llllllll}
\hline Effect & & Value & $\mathrm{F}$ & Hypothesis df & Error df & Sig. & Partial Eta Squared \\
\hline \multirow{2}{*}{ Intercept } & Pillai's Trace & .993 & $5979.675^{\mathrm{b}}$ & 7.000 & 288.000 & .319 & .993 \\
\cline { 2 - 8 } & Wilks' Lambda & .007 & $5979.675^{\mathrm{b}}$ & 7.000 & 288.000 & .319 & .993 \\
\cline { 2 - 8 } & Hotelling's Trace & 145.339 & $5979.675^{\mathrm{b}}$ & 7.000 & 288.000 & .319 & .993 \\
\cline { 2 - 8 } group & Roy's Largest Root & 145.339 & $5979.675^{\mathrm{b}}$ & 7.000 & 288.000 & .319 & .993 \\
& Pillai's Trace & .832 & $203.491^{\mathrm{b}}$ & 7.000 & 288.000 & .319 & .832 \\
\cline { 2 - 8 } & Wilks' Lambda & .168 & $203.491^{\mathrm{b}}$ & 7.000 & 288.000 & .319 & .832 \\
\cline { 2 - 8 } & Hotelling's Trace & 4.946 & $203.491^{\mathrm{b}}$ & 7.000 & 288.000 & .319 & .832 \\
\cline { 2 - 8 } & Roy's Largest Root & 4.946 & $203.491^{\mathrm{b}}$ & 7.000 & 288.000 & .319 & .832 \\
\hline \multicolumn{2}{l}{ a. Design: Intercept + group } & & & & & &
\end{tabular}

b. Exact statistic

Table 5 depicts that pre and in -service teachers do not significantly differ with respect to their attitudes towards the coverage of all knowledge areas except for theory which confirms what was previously discussed using descriptive statistics, namely the mean scores. In fact, this is in line with what was already mentioned. Both groups of teachers believe that traditional knowledge areas including language concepts and theoretical principles are mostly covered in teacher education programs.

R.Q.2. To what extent the knowledge areas covered during pre-service and in-service teacher education programs are found to be effective for practical teaching from the perspectives of Iranian EFL student teachers and practicing teachers?

The KBEQ was also administered to 140 pre-service student teachers and 160 inservice practicing teachers in order to determine their perceptions of the effectiveness of the seven knowledge base areas. It was actually intended to specify to what extent each knowledge base area is perceived to be helpful and effective while practical teaching. In so doing, the mean scores calculated for each knowledge base area were also taken into account. The results are illustrated in Table 6. 
Table 6

Descriptive Statistics for Pre-Service Teachers' Attitudes towards The Effectiveness of the Knowledge Base Covered in Teacher Education

\begin{tabular}{llllll}
\hline & $\mathrm{N}$ & Minimum & Maximum & Mean & Std. Deviation \\
\hline materials & 140 & 1.25 & 2.00 & 1.6504 & 1.14334 \\
\hline Post-method & 140 & 1.50 & 2.83 & 1.7398 & .27299 \\
\hline awareness & 140 & 1.80 & 3.20 & 2.3500 & .35105 \\
\hline theory & 140 & 1.50 & 9.00 & 2.3955 & .67183 \\
\hline research & 140 & 2.14 & 3.00 & 2.1605 & .21237 \\
\hline total & 140 & 2.29 & 3.82 & 2.4657 & .15134 \\
\hline language & 140 & 2.00 & 3.50 & 2.7196 & .38106 \\
\hline Learner issues & 140 & 2.33 & 3.83 & 2.8226 & .35381 \\
\hline
\end{tabular}

The results presented in Table 6 indicates that "learner issues" and "language concepts" were perceived to be the most useful knowledge areas as their mean scores were 2.8226 and 2.7196 respectively. In fact, pre-service teachers declared that the content of the teacher education programs should be more allocated to these two knowledge areas so that they would possess the necessary linguistics skills and can be responsive and sensitive to their learners' individual differences and needs. Although, Kumaravadivelu (2006) asserted that deriving a manageable list of communicative needs for a group of learners each following his own objective seems unrealistic, such results show that pre-service teachers' minds may be occupied with the questions related to learners' needs and the linguistics knowledge needed for teaching.

"Materials development" and "post method indicators" knowledge areas were, however, perceived to be the least useful. The mean scores for these two knowledge areas were respectively 1.65 and 1.73 noticeably less than half of the possible maximum score. According to the validation study conducted by Jadidi and Bagheri (2014), items such as item 10 (designing syllabus) and item 12 (practical textbook design and production) in KBEQ are relevant to " materials development'" and items 20 (teachers' reflection), item 21 (critical pedagogy) and item 22 (post-method teaching) are referred to as " post-method indicators" knowledge areas. The pre-service teachers' perceptions regarding these two knowledge areas are actually not in line with current pedagogic concerns in foreign language education. In fact, knowledge areas such as syllabus design which is a common reference point that sets the stage for learning throughout the course, teacher reflection which is a tool for teachers to observe and evaluate the way they behave in the classroom and find out what goes on in their classroom, critical pedagogy which is a teaching philosophy to encourage students to take control of their own learning and critically evaluate the opinions they have been taught to have, and postmethod pedagogy which is a way to value teachers' potentials and encourage them to construct their own methods, are among the most important knowledge areas in current foreign language education which were considered the least effective issues by preservice teachers. 
Table 7

Descriptive Statistics for In-Service Teachers' Attitudes towards the Effectiveness of the Knowledge Base Covered in Teacher Education

\begin{tabular}{llllll}
\hline & $\mathrm{N}$ & Minimum & Maximum & Mean & Std. Deviation \\
\hline languageE & 160 & 1.25 & 3.00 & 2.4946 & .38424 \\
\hline issuesE & 160 & 1.33 & 3.00 & 2.5573 & .34963 \\
\hline awarenessE & 160 & 1.40 & 3.20 & 2.5587 & .41000 \\
\hline totalE & 158 & 2.00 & 3.00 & 2.6222 & .15883 \\
\hline theoryE & 159 & 1.50 & 3.50 & 2.6583 & .44485 \\
\hline matarialsE & 160 & 1.25 & 4.25 & 2.8969 & .99028 \\
\hline researchE & 159 & 2.00 & 3.86 & 2.9605 & .50262 \\
\hline postmethodE & 160 & 1.50 & 4.25 & 3.2266 & .47814 \\
\hline Valid N (listwise) & 158 & & & & \\
\hline
\end{tabular}

Comparing the results in Tables 6 and 7, one can detect two noticeable divergences in the perception of pre-service and in-service teachers regarding the helpfulness of the knowledge base areas for actual practice inside the classrooms. First, in contrast to preservice teachers who reported that post-method indicators of knowledge area are not really what they need in practical teaching, in-service teachers declared that they are highly useful for practicing teachers. Such a discrepancy can be related to the significant role of experience in shaping teachers' perceptions or attitudes toward teaching and learning issues. 'Post-method indicators"' is not perceived to be useful for practical teaching by pre-service teachers probably due to the fact that they do not have immediate teaching needs in class. Secondly, by comparing with pre-service teachers' perceptions, almost all knowledge areas which are related to teachers' contextual sensitivity and functioning were noticeably more useful from the perspective of inservice teachers.

In order to determine the significance of the differences in the views of pre and inservice teachers regarding the effectiveness of the knowledge areas mentioned and elaborated above, Multivariate analysis of variance was also utilized. The results are presented in Table 8, Table 9, and Table 10.

Table 8

Between-Subjects Factors

\begin{tabular}{cclc}
\hline & & Value Label & $\mathrm{N}$ \\
\hline \multirow{2}{*}{ group } & 1 & in-service & 160 \\
\cline { 2 - 4 } & 2 & pre-service & 140 \\
\hline
\end{tabular}


Table 9

Multivariate Testsa

\begin{tabular}{llllllll}
\hline Effect & & Value & F & $\begin{array}{l}\text { Hypothesis } \\
\text { df }\end{array}$ & Error df & Sig. & $\begin{array}{l}\text { Partial } \\
\text { Eta } \\
\text { Squared }\end{array}$ \\
\hline Intercept & & & & & & & \\
& Pillai's Trace & .998 & $18486.221^{\mathrm{b}}$ & 8.000 & 283.000 & .000 & .998 \\
\cline { 2 - 8 } & Wilks' Lambda & .002 & $18486.221^{\mathrm{b}}$ & 8.000 & 283.000 & .000 & .998 \\
\cline { 2 - 8 } & Hotelling's Trace & 522.579 & $18486.221^{\mathrm{b}}$ & 8.000 & 283.000 & .000 & .998 \\
\hline group & Roy's Largest Root & 522.579 & $18486.221^{\mathrm{b}}$ & 8.000 & 283.000 & .000 & .998 \\
& Pillai's Trace & .453 & $29.285^{\mathrm{b}}$ & 8.000 & 283.000 & .000 & .453 \\
& Wilks' Lambda & .547 & $29.285^{\mathrm{b}}$ & 8.000 & 283.000 & .000 & .453 \\
\cline { 2 - 8 } & Hotelling's Trace & .828 & $29.285^{\mathrm{b}}$ & 8.000 & 283.000 & .000 & .453 \\
\hline
\end{tabular}

a. Design: Intercept + group

b. Exact statistic

Inspecting the Column which is entitled " Wilks' Lambda" in the group section of Table 9, it becomes apparent that there is a significant difference between pre-service and in-service teachers' attitudes towards the effectiveness of the knowledge base areas that are currently covered in teacher education programs in Iran. However, as mentioned before, Tests of Between-Subjects Effects should also be checked to determine the significance of the differences among all dependent variables, the knowledge areas. The results are illustrated in Table 10.

Table 10

Tests of Between-Subjects Effects

\begin{tabular}{clrrrrrr}
\hline \multirow{2}{*}{ Source } & $\begin{array}{l}\text { Dependent } \\
\text { Variable }\end{array}$ & $\begin{array}{c}\text { Type III Sum of } \\
\text { Squares }\end{array}$ & df & $\begin{array}{c}\text { Mean } \\
\text { Square }\end{array}$ & F & Sig. & Partial Eta Squared \\
\hline \multirow{6}{*}{ group } & .957 & 1 & .957 & 9.570 & .002 & .032 \\
\cline { 2 - 8 } & Issues & 1.866 & 1 & 1.866 & 11.286 & .001 & .037 \\
\cline { 2 - 8 } & Theory & 2.986 & 1 & 2.986 & 10.161 & .002 & .000 \\
\cline { 2 - 8 } & Language & 19.135 & 1 & 19.135 & 103.061 & .000 & .262 \\
\cline { 2 - 8 } & Post-method & 2.867 & 1 & 2.867 & 19.251 & .000 & .062 \\
\cline { 2 - 8 } & Awareness & 61.530 & 1 & 61.530 & 77.117 & .000 & .210 \\
\cline { 2 - 8 } & Materials & 1.767 & 1 & 1.767 & 79.741 & .000 & .216 \\
\cline { 2 - 8 } & Total & 18.868 & 1 & 18.868 & 121.436 & .000 & .295 \\
\cline { 2 - 8 }
\end{tabular}

Table 10 depicts that pre and in-service teachers significantly differ with respect to their attitudes towards the effectiveness of all knowledge areas currently presented to teachers in teacher education programs in Iran. In fact, significant differences were particularly detected for the knowledge areas that demand context-sensitive functioning on the part of the teachers. It was mentioned in the previous section that such knowledge areas are perceived to be more effective than more traditional ones such as language concepts and theoretical knowledge from the perspective of both groups of teachers. However, these knowledge areas were far more effective from the perspective of in-service teachers which can be due to their contextual experiences.

\section{DISCUSSION}

Education plays a crucial role in the development of a country and teachers have a key role in directing the future of the country. Education aims are both academic and social. 
Effective teachers, equipped with the latest pedagogic techniques will encourage the economic development and future welfare of a country. This study was, in fact, a comprehensive endeavour to evaluate pre-service and in-service language teacher education in Iran through determining the extent to which knowledge base areas were covered as well as the extent to which such issues were found to be effective for practical teaching based on the teachers' perspectives. It was realized that although both pre-service and in-service teachers admitted that the knowledge base of teachereducation programs in Iran is more allocated to areas traditionally conceived to be useful for student teachers such as theoretical principles and language concepts rather than those that constitute much of currents pedagogic concerns such as teachers' skill in adapting learning materials to suit particular educational contexts or their developing capabilities in conducting action research to solve practical problems.

The findings of the current study was also in line with what the National Curriculum Framework (2005) highlighted three systemic concerns of teacher education (a) in current teacher education practices, knowledge is treated as 'given', embedded in the curriculum and accepted without question (b) the language proficiency of the teacher needs to be significantly increased from its abysmally low levels, and the centrality of language in the curriculum ought to be acknowledged and third (c) teacher education programs do not offer any scope for student teachers to reflect on their classroom experiences, thereby failing to empower them as agents of change. Therefore, as mentioned previously, there is a lack of balance between pedagogical competence and linguistics in that the pedagogic facet of the pre-service teacher education program is rather effete, as it does not offer adequate opportunities for teaching practices. In-service teachers also criticized the irrelevance of much of information and content presented to them in in-service teacher education. The importance of teaching practice can hardly be overemphasized: for instance, it lends realism to the whole course as it gives prospective teachers the opportunity to experience the efficacy of what they have imbibed in class (Dogancay-Aktuna \& Kiziltepe, 2005). In essence, the current system is primarily based on theory as opposed to being practice-based one in which student teachers put theoretical aspects and elements of their course into use in the classroom (Karakas, 2012). It should not, however, be forgotten that a curriculum cannot reflect what is covered and how it is covered on a program of study in any precise sense. Adaptations and amendments to the curriculum and to what was originally intended by teacher educators (at both pre-service and in-service levels) adapt the available material to suit their purposes and to fit their current capacities as they deliver these programs. The missing elements and weaknesses in the syllabuses require teachers to fill these gaps and correct these weaknesses, in the context of their own teaching practice and in terms of any implementation constraints they encounter (Borg, et al., 2014).

\section{CONCLUSION}

The issues of pre-service and in-service teacher education in Iran are so intricate and that a single study cannot address them comprehensively and simultaneously. The scope of the present study can, therefore, only contributes to paving the ground for more context-specific inquiries in the field. In fact, this study only investigated the coverage 
and effectiveness of the knowledge base of pre and in-service teacher education as perceived by Iranian EFL teachers. The main intention, however, was to evaluate the current status of teacher education in Iran to determine if it has been developed and adjusted in line with the recent pedagogical concerns which emphasize teachers' capabilities to function effectively in local contexts.

In the present educational milieu in which teachers are playing various roles such as a teacher, a researcher, a material producer, and a syllabus designer, issues like theoretical concepts, learner-related issues, and language concepts are perceived to be less important than subjects such as research skills, teacher awareness, and post-method pedagogy. Referring to the results of the present study, it was revealed that teacher education programs in Iran are mainly designed to focus on the knowledge areas which are proved to be less effective for solving the actual problems that teachers encounter while teaching. It is worth mentioning that teachers' autonomy which is strongly emphasized in the post-method era, cannot be attained unless teachers' awareness of their own style, beliefs, and their learners' needs, motivation and culture is fulfilled as a prerequisite. Both pre and in-service teacher education programs should invest more on improving prospective and practicing teachers' critical capabilities to reflect on their own identities. As Izadinia (2012) asserted, although critical pedagogy has brought positive changes in students and teachers' social and personal lives, it does not seem to have gained a comfortable position in second language teacher education in Iran. Thus, it is unlikely to think that teacher education programs in Iran can produce autonomous and critical teachers who are equipped with the knowledge base to face the contextspecific teaching challenges.

\section{REFERENCES}

Borg, S., Birello, M., Civera, I., \& Zonatta, T. (2014). The impact of teacher education on pre- service primary English language teachers. ELT Research Papers, 14 (3), 1-32.

Calderhead, J. (1988). The development of knowledge structure in learning to teach. In Calderhead (Ed.) Teachers' professional learning,51-64. London. England: The Falmer Press.

Casey, M.A., \& McWilliam, A.R. (2008). Graphical feedback to increase teachers' use of incidental teaching. Journal of Early Intervention,30(3), 251-268.

Day, R. (1993). Models and the knowledge base of second language teacher education. Working papers in Second language studies,11(2),1-113.Retrieved from http://hawaii.edu/sls/uhwpesl/11/Day.pdf.

Dehghan, A. (1950). Teacher Education: In France, England and Iran. Tehran: University Press.

Dogancay-Aktuna, S., \& Kiziltepe, Z.K. (2005). English in Turkey. World Englishes, 24(2), 253- 265.

Elbaz, F. (1983). Teacher thinking: A study of practical knowledge. London: Crown Helm. 
Fandino, Y. (2013). Knowledge base and EFL teacher education programs: a Colombian perspective. Ikala, revistade lenguaje y cultura, 18(1),83-95.

Fenstermacher, G.D. (1994). The knower and the known: The nature of knowledge in research on Teaching. Review of Educational Research,20,3-56.

Freeman, D. (1991). Three views to teachers' knowledge. IATEFL Teacher Development Newsletter,1-4.

Freeman, D. (1993). Renaming experience/reconstructing practice: Developing new understandings of teaching. Teaching and Teacher Education, 94, 485-497.

Freeman, D., \& Johnson, K. (1998). Reconceptualizing the knowledge-base of language teacher education. TESOL Quarterly ,38(1) ,397-417. Freeman, D. (1991). Three views to teachers' knowledge. IATEFL Teacher Development Newsletter,1-4.

Freeman, D. (1993). Renaming experience/reconstructing practice: Developing new understandings of teaching. Teaching and Teacher Education, 94, 485-497.

Guerriero, S. (2014). Teachers' Pedagogical Knowledge and the Teaching Profession. OECD Publishing.

Izadinia, M. (2012). Teacher educators as role models: A qualitative examination of student teachers' \& teacher educators' views towards their roles. The Qualitative Report,17(47), 1-15 Retrieved from http://www.nova.edu/sss/QR/QR17/izadnia.pdf.

Jadidi, E., \& Bagheri, M.S. (2014). ELT Pre-Service Teacher Education: Major Trends and Shifts. International Journal of Language Learning and Applied Linguistics World,7(4),181-190.

Karakas, A. (2012). Evaluation of the English Language Teacher Education Program in Turkey. ELT Weekly Journal, 4(15), 1-4. Retrieved from http://www.eltweekly.com/eltnewsletter/2012/04/vol-4-issue-15.

Kaur, G., Yuen, C., \& Kaur, S. (2011). Assessing ESL teacher trainees' content, pedagogical, and professional knowledge base. The assessment handbook,4(2),4-15.

Kazemi, A., \& Ashrafi, M. (2014). In-service Training for Iranian Teachers Revisited. International Journal of Asian Science, 4(10), 1062-1076.

Khanjani, A., Vahdany, F., \& Jafarigohar, M. (2016). The EFL Pre-service Teacher Training in Iran: Is it Adequate or not? Iranian Journal of English for Academic Purposes, 5(1), 1-22.

Khanjani, A., Vahdany, F., \& Jafarigohar, M. (2017). EFL Teacher Education in Iran: Does it promote Trainees' Pedagogical Content Knowledge? Journal of Research in Applied Linguistics, 8(2), 159-186.

Kumaravadivelu, B. (2006). Understanding language teaching: From method to postmethod. Mahwah, NJ: Lawrence Erlbaum. 
Kumaravadivelu, B. (2012). Language teacher education for a global society: A modular model for knowing, analysing, recognizing, doing, and seeing. New York: Routledge.

Lafayette, R.C. (1993). Subject -matter content: What every foreign language teacher needs to know. In Gunterman (Ed). Developing language teachers for a changing world,125- 157.Lincolnwood, IL: National Textbook.

Lucas, T., Viillegas, M.A., \& Freedson-Gonzalez, M. (2008). Linguistically responsive teacher education: Preparing classroom teachers to teach English language learners. Journal of Teacher Education 59(4),361-373.

Lynch, J., \& Plunkett, H. (1973)." Introduction in Teacher Education and Cultural changes: England, France, and West Germany", Hamden, Connecticut: The shoe String Press, Inc.,1973. p.15(1).

Manouchehri, A. (2002). Developing teaching knowledge through peer discourse. Teaching and Teacher Education, 18,715-737.Retrieved from http://www.se.rit.edu/ swami/LearningPapers/Manouchehri2002PeerDiscourse.pdf

Mehrani, M., \& Mohammad Tatari, M. (2016). An Evaluation of Language Teacher Education Program in Farhangian University of Bojnourd. Modern Journal of Teaching Methods, 6(2), 81- 89.

Mirhassani, S.A., \& Beh-Afarin, S.R. (2004). EFL teacher training evaluation: Assessment of needs, pedagogical constraints and objective setting in EFL teacher training programs (TEPs). Roshd FLT Quarterly, 69(18), 45-57.

Moon, B., Leach, J., \& Stevens, M.P. (2005). Designing open and distance learning for teacher Education in sub-Sahara Africa: A toolkit for educators and planners. Harvard: Africa Region Human Development.

National Institute of Education. (1975). Teaching as clinical information processing. (No. Panel 6, National Conference on Studies in Teaching): National Institute of Education.

Nelson, A. (2007). Teacher training course. Delhi: Global Media.

Noora, A. (2008). Iranian undergraduate non-English majors' language learning preferences. GEMA Online Journal of Language Studies, 8(2), 33-44.

Ohata, K. (2007). Teacher development or training? Recent developments in second/foreign language teacher education. The language teacher bulletin,22(1),1-16. Retrieved from http: web.icu.ac.jp/Irb/vol- 22/Kota\%20LRB\%20V22.pdf

Peacock, M. (2009). Attribution and learning English as a foreign language. ELT Journal,64(2), 184-192.

Pineda, C. (2002). Knowledge base for ESL/EFL educators: What does it mean? Profile Issues in teachers' professional development 3,9-14. 
Razi, N., \& Kargar, A. A. (2014). Evaluation of in-service foreign language teacher education program in Iran.Intrnational Journal of Language Learning and Applied Linguistics World, 5(1), 221-236.

Richards, J.C. (1998). Beyond training. United States of America: Cambridge University Press.

Richards, J.C., \& Rodgers, T.S. (2001). Approaches and methods in language teaching $\left(2^{\text {nd }}\right.$ ed. $)$. Cambridge: Cambridge University Press.

Richards, J.C., \& Schmidt, R. (1985). Dictionary of language teaching and applied linguistics. London: Pearson Education.

Safi, A. A. (2009). Methods of educational measurement and evaluation. Tehran: Doran publisher

Shahmohammadi, N. (2012). Evaluation of teachers 'education programs in Iran (case study). Journal of Educational and Social Research, 2(2),127-135.

Shulman, L.S. (1987). Knowledge and teaching: Foundations of the new reform. Harvard Educational Review, 57(1), 1-22.

Tarone, E., \& Allwright, R.L. (2005). Language teacher learning and student language learning: Shaping the knowledge base. In D.J. Tedick(Ed), Second language teacher Education: International perspectives, 5-23. USA: Lawrence Erlbaum Publishers.

Wallace, M. (1991) Training foreign language teachers: A reflective approach. Cambridge, England: CUP.

Wedell, M. (1992). Pre/in service training of ELT teacher trainers: Planning the regional MATEFL project. In Flowerde, J., Brock, M. and Hsia, S. (Eds.), Perspectives on second language teacher education, 337-350. Hong Kong: City University of Hong Kong.

Zeichner, K. (1999). The new scholarship in teacher education. Educational Researcher, 28 (9), 4-15. 


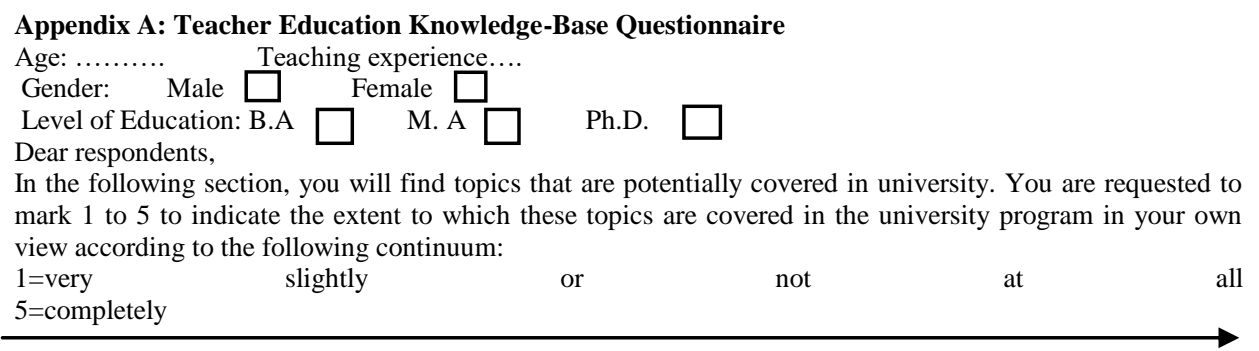

If you think a topic is missing, you may add it to the end of the list and indicate its degree of coverage. If you have any further comments about each topic, you may mention it at the end of each questionnaire. Thank you very much in advance for your time and cooperation.

\begin{tabular}{|c|c|c|c|c|c|c|}
\hline \multirow[t]{2}{*}{ NO } & \multirow[t]{2}{*}{ Topics } & \multicolumn{5}{|c|}{ Degree of Coverage } \\
\hline & & 1 & 2 & 3 & 4 & 5 \\
\hline 1 & Second language acquisition theories & & & & & \\
\hline 2 & First language acquisition theories & & & & & \\
\hline 3 & Language theories & & & & & \\
\hline 4 & Methods of language teaching: GTM-ALM-CLY-TPR... & & & & & \\
\hline 5 & Theories of language testing & & & & & \\
\hline 6 & Test construction and design procedures & & & & & \\
\hline 7 & Test qualities (validity-reliability...) & & & & & \\
\hline 8 & Teaching language skills & & & & & \\
\hline 9 & Teaching the sub-skills (grammar-vocabulary-pronunciation) & & & & & \\
\hline 10 & Syllabus design & & & & & \\
\hline 11 & Textbook production(theories) & & & & & \\
\hline 12 & Textbook production (practical) & & & & & \\
\hline 13 & Classroom management skills (talk and topic management) & & & & & \\
\hline 14 & Communication strategies & & & & & \\
\hline 15 & Learning strategies & & & & & \\
\hline 16 & Learners 'learning styles (field in/dependence -tolerance of ambiguity...) & & & & & \\
\hline 17 & Learner internal factors that affect L2 learning (age-anxiety-attitudes-motivation...) & & & & & \\
\hline 18 & Learner external factors that affect L2 learning (social and educational contexts...) & & & & & \\
\hline 19 & Mental learning mechanisms (input/intake processing-memory-elaboration...) & & & & & \\
\hline 20 & Teacher reflection on/in action & & & & & \\
\hline 21 & Critical pedagogy & & & & & \\
\hline 22 & Post method pedagogy & & & & & \\
\hline 23 & Analysing and understanding learners' needs & & & & & \\
\hline 24 & Analysing and understanding learners 'motivation & & & & & \\
\hline 25 & Analysing and understanding learners' autonomy & & & & & \\
\hline 26 & The effect of teachers "beliefs, and values on teaching behaviour and learning outcomes & & & & & \\
\hline 27 & The way teachers construct their personal knowledge & & & & & \\
\hline 28 & Phonological theory & & & & & \\
\hline 29 & Morphology (words and their parts-derivations and inflections) & & & & & \\
\hline 30 & Syntax (the structure of the sentences-differences in syntax across languages) & & & & & \\
\hline 31 & Fundamental semantics (word meaning-pragmatics) & & & & & \\
\hline 32 & Discoursal features of language (language in context-language as talk and communication) & & & & & \\
\hline 33 & Languages and their particular world views & & & & & \\
\hline 34 & Relationship of language to power and dominance & & & & & \\
\hline 35 & Functions of language & & & & & \\
\hline 36 & Relationship of form, meaning and communicative intents & & & & & \\
\hline 37 & Cross cultural differences and L2 learning & & & & & \\
\hline 38 & Research methods in L2 learning & & & & & \\
\hline 39 & Research findings in the field & & & & & \\
\hline 40 & Form-focused instruction & & & & & \\
\hline 41 & Action research & & & & & \\
\hline 42 & Teacher inquiry & & & & & \\
\hline 43 & Strategy-based instruction & & & & & \\
\hline 44 & Writing lesson plan & & & & & \\
\hline 45 & Critical discourse analysis & & & & & \\
\hline
\end{tabular}

International Journal of Instruction, October $2018 \bullet$ Vol.11, No.4 


\section{Appendix B: Knowledge-Base Effectiveness Questionnaire}

Age: .......... Teaching experience.

Gender: Male $\square$ Female

Level of Education: B.A $\square$ M. A $\square$

Dear respondents,

In the following section, you will find topics that are potentially covered in university program. You are requested to mark 1 to 5 to indicate the extent to which these topics are useful for practical teaching in your own view according to the following continuum:

$1=$ very slightly

or

not

at

all

$5=$ completely

If you think a topic is missing, you may add it to the end of the list and indicate its degree of usefulness. If you have any further comments about each topic, you may mention it at the end of each questionnaire. Thank you very much in advance for your time and cooperation.

\begin{tabular}{|c|c|c|c|c|c|c|}
\hline \multirow[t]{2}{*}{ NO } & \multirow[t]{2}{*}{ Topics } & \multicolumn{5}{|c|}{ Usefulness for Teaching } \\
\hline & & 1 & 2 & 3 & 4 & 5 \\
\hline 1 & Second language acquisition theories & & & & & \\
\hline 2 & First language acquisition theories & & & & & \\
\hline 3 & Language theories & & & & & \\
\hline 4 & Methods of language teaching: GTM-ALM-CLY-TPR... & & & & & \\
\hline 5 & Theories of language testing & & & & & \\
\hline 6 & Test construction and design procedures & & & & & \\
\hline 7 & Test qualities (validity-reliability...) & & & & & \\
\hline 8 & Teaching language skills & & & & & \\
\hline 9 & Teaching the sub-skills (grammar-vocabulary-pronunciation) & & & & & \\
\hline 10 & Syllabus design & & & & & \\
\hline 11 & Textbook production(theories) & & & & & \\
\hline 12 & Textbook production (practical) & & & & & \\
\hline 13 & Classroom management skills (talk and topic management) & & & & & \\
\hline 14 & Communication strategies & & & & & \\
\hline 15 & Learning strategies & & & & & \\
\hline 16 & Learners 'learning styles (field in/dependence -tolerance of ambiguity...) & & & & & \\
\hline 17 & Learner internal factors that affect L2 learning (age-anxiety-attitudes-motivation...) & & & & & \\
\hline 18 & Learner external factors that affect L2 learning (social and educational contexts...) & & & & & \\
\hline 19 & Mental learning mechanisms (input/intake processing-memory-elaboration...) & & & & & \\
\hline 20 & Teacher reflection on/in action & & & & & \\
\hline 21 & Critical pedagogy & & & & & \\
\hline 22 & Post method pedagogy & & & & & \\
\hline 23 & Analysing and understanding learners' needs & & & & & \\
\hline 24 & Analysing and understanding learners 'motivation & & & & & \\
\hline 25 & Analysing and understanding learners' autonomy & & & & & \\
\hline 26 & The effect of teachers "beliefs, and values on teaching behaviour and learning outcomes & & & & & \\
\hline 27 & The way teachers construct their personal knowledge & & & & & \\
\hline 28 & Phonological theory & & & & & \\
\hline 29 & Morphology (words and their parts-derivations and inflections) & & & & & \\
\hline 30 & Syntax (the structure of the sentences-differences in syntax across languages) & & & & & \\
\hline 31 & Fundamental semantics (word meaning-pragmatics) & & & & & \\
\hline 32 & Discoursal features of language (language in context-language as talk and communication) & & & & & \\
\hline 33 & Languages and their particular world views & & & & & \\
\hline 34 & Relationship of language to power and dominance & & & & & \\
\hline 35 & Functions of language & & & & & \\
\hline 36 & Relationship of form, meaning and communicative intents & & & & & \\
\hline 37 & Cross cultural differences and L2 learning & & & & & \\
\hline 38 & Research methods in L2 learning & & & & & \\
\hline 39 & Research findings in the field & & & & & \\
\hline 40 & Form-focused instruction & & & & & \\
\hline 41 & Action research & & & & & \\
\hline 42 & Teacher inquiry & & & & & \\
\hline 43 & Strategy-based instruction & & & & & \\
\hline 44 & Writing lesson plan & & & & & \\
\hline 45 & Critical discourse analysis & & & & & \\
\hline
\end{tabular}

International Journal of Instruction, October $2018 \bullet$ Vol.11, No.4 